Abstracta Iranica Abstracta Iranica

Revue bibliographique pour le domaine irano-aryen

Volume 31 | 2011

Comptes rendus des publications de 2008

\title{
Uyghur änäniwi äkhlaqi. Urumchi, Shinjang khälq näshriyati, 2005, 310 p. [Les vertus traditionnelles des Ouïgours]
}

Alexandre Papas

\section{(2) OpenEdition}

1 Journals

Édition électronique

URL : http://journals.openedition.org/abstractairanica/39821

DOI : 10.4000/abstractairanica.39821

ISSN : 1961-960X

Éditeur :

CNRS (UMR 7528 Mondes iraniens et indiens), Éditions de l'IFRI

Édition imprimée

Date de publication : 15 mai 2011

ISSN : 0240-8910

Référence électronique

Alexandre Papas, « Uyghur änäniwi äkhlaqi. Urumchi, Shinjang khälq näshriyati, 2005, 310 p. [Les vertus traditionnelles des Ouïgours] », Abstracta Iranica [En ligne], Volume 31 | 2011, document 299, mis en ligne le 11 octobre 2012, consulté le 27 septembre 2020. URL : http://journals.openedition.org/ abstractairanica/39821 ; DOI : https://doi.org/10.4000/abstractairanica.39821

Ce document a été généré automatiquement le 27 septembre 2020

Tous droits réservés 


\title{
Uyghur änäniwi äkhlaqi. Urumchi, Shinjang khälq näshriyati, 2005, 310 p. [Les vertus traditionnelles des Ouïgours]
}

\author{
Alexandre Papas
}

Depuis quelques années, comme dans d'autres provinces l'intelligentsia officielle du Xinjiang publie régulièrement des articles, brochures et ouvrages vantant les traditions et la morale de la minorité ouïgoure. L'intention est évidemment de policer par le haut une population suspectée de tendances séditieuses sinon séparatistes. Le livre de Qorghan est un exemple typique et relativement bien fait de cette littérature normative. Il s'agit de passer en revue pratiques et institutions humaines (valeurs morales individuelles et collectives, bienséance, famille, relations hommes/femmes, écologie, travail, éducation) selon les grands auteurs turkestanais, comme Yūsuf Huāṣs Ḥajib (XI s.), Muḥammad 'Abdullāh Ḩarābātī (XVII-XVIII s.), Muḥammad Ṣiddīq Rašīdī (XVIII ${ }^{e}$ s.), 'Abduqādir Dāmullāh (XIXe s.) agrémentées de quelques références au Coran et aux hadiths. L'intérêt de cette curieuse anthologie des bonnes mœurs ouïgoures ne réside pas tant dans sa description du comportement idéal que dans la thèse qu'elle sous-tend : en substance, l'héritage intellectuel centrasiatique contribue à l'édification d'un bon citoyen du Xinjiang.

\section{INDEX}

Thèmes : 13.3. Asie centrale 
AUTEURS

ALEXANDRE PAPAS

CNRS - Paris 